\title{
MESOPHILIC-THERMOPHILIC FERMENTATION PROCESS OF WASTE ACTIVATED SLUDGE AFTER HYBRID DISINTEGRATION
}

\author{
FERMENTACJA MEZOFILOWO-TERMOFILOWA OSADU \\ DEZINTEGROWANEGO W PROCESIE HYBRYDOWYM
}

\begin{abstract}
The previously received results of individual processes of hydrodynamic and alkaline disintegration were decisive significant for the conducted research task. The combination of hydrodynamic cavitation (30 minutes duration of the process) and alkaline $(\mathrm{pH} \approx 9)$ to the destruction of activated sludge caused a significant release of organic matter about $1383 \mathrm{mg} / \mathrm{dm}^{3}$ in comparing to individual processes. Such increase in the SCOD value resulted in a significant growth the efficiency of biogas yield in a two-stage mesophilic-thermophilic processes. The increase in yield was from 26 to $38 \%$ depending on the volume of disintegrated sludge. The effect of the two-stage fermentation resulted activated sludge hygienisation. The microbiological analysis of the influence of the fermentation with the different volume of hybrid disintegrated sludge was based on microbiological indicators: Salmonella spp. and coliphages. The obtained results prove the effectiveness of the two-stage digestion process compared to single mesophilic fermentation which not always completely eliminates the above indicators.
\end{abstract}

Keywords: hybrid disintegration, two stage fermentation, biogas, higienisation of sewage sludge

\section{Introduction}

Sludge disposal is problematic and expensive - treatment costs oscillate up to $60 \%$ of total operating costs of wastewater treatment plants (WWTPs) [1]. Sludge from sewage treatment plants contains high amounts of nutrients and organic matter. The use of sludge as fertilizer for farmland is recommended from a recycling point of view. However, sludge can contain significant amounts of pathogenic microorganisms. These microorganisms can be eliminated in the disintegration process of sewage sludge and then in fermentation and/or chemical sludge hygienisation ie by the use of lime. Destruction of the microbial cells in the

\footnotetext{
${ }^{1}$ Department of Environmental Microbiology and Biotechnology, Institute of Environmental Protection and Engineering, University of Bielsko-Biala, ul. Willowa 2, 43-309 Bielsko-Biała, Poland, phone +48 338279157

${ }^{2}$ Institute for Nanomaterials, Advanced Technology and Innovation, Technical University of Liberec, Studentská 1402/2, 46117 Liberec 1, Czech Republic, phone +420 485353006

*Corresponding author: kgrubel@ath.bielsko.pl
} 
process of disintegration released of organic matter to the aqueous phase and accelerates the first step of fermentation - hydrolysis, which is known as the rate-limiting step of degradation of particulate organic matter in sludge [2]. Anaerobic digestion is a common method for activated sludge stabilization resulting in the reduction of sludge volatile matter and the production of biogas. Anaerobic degradation of biomass and extracellular polymeric substances (EPS) is considered to follow a sequence of four phases: hydrolysis, acidogenesis, acetogenesis and methanogenesis. A wide range of treatments have been examined for their potential to improve waste activated sludge (WAS) digestibility during mesophilic/thermophilic anaerobic digestion [3, 4]. Digestibility has been improved by mechanical [5-7], thermal [8,9], chemical [10], ultrasonic [11] and hybrid [3, 12] pre-treatments.

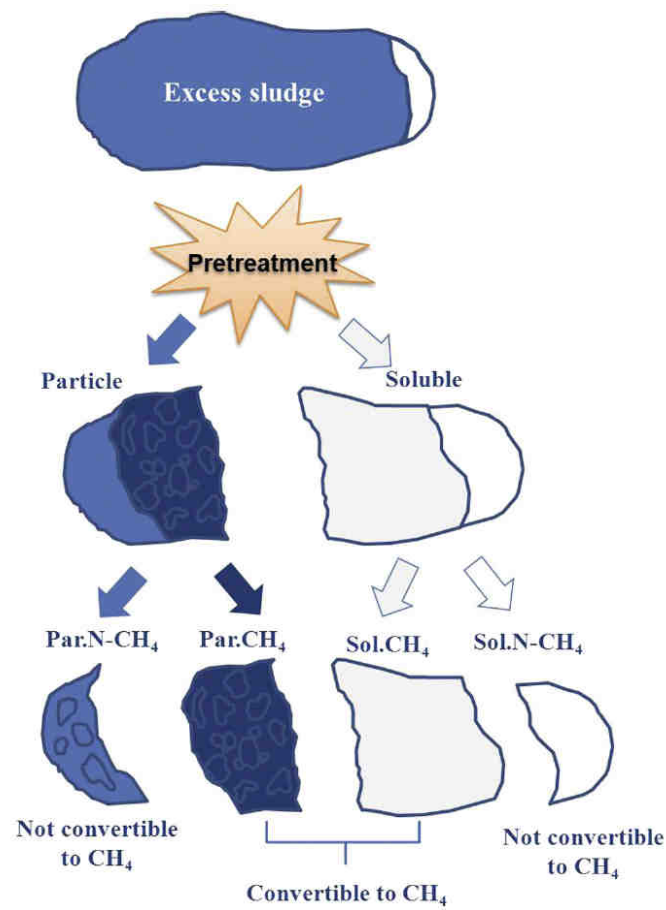

Fig. 1. Division of pretreated excess sludge into four parts (Par.N-CH 4 : particle and not convertible to $\mathrm{CH}_{4}$; Par. $\mathrm{CH}_{4}$ : particle but convertible to $\mathrm{CH}_{4}$; Sol. $\mathrm{CH}_{4}$ : soluble and convertible to $\mathrm{CH}_{4}$; Sol.N-CH : soluble but not convertible to $\mathrm{CH}_{4}$ ) [1]

In our recent studies, we showed a positive effect of alkalization on the solubilization of the WAS and yield of biogas which was $22 \%$ higher in comparison with blank sample [13]. Li et al [14] conducted alkaline post-treatment test in order to improve sludge anaerobic digestion, he extracted $5 \%$ of sludge from the digester, disintegrated with $0.1 \mathrm{~mol} / \mathrm{L} \mathrm{NaOH}$ and returned to the digester. They achieved $33 \%$ enhancement of biogas production in comparison with the control sample [14]. Positive effects using alkalization combined with other treatments, observed also Lee and Hen [7]. They observed 
a significant synergy effect of hydrodynamic cavitation assisted with $\mathrm{NaOH}$ pretreatment, which led to the higher cumulative yield of $\mathrm{CH}_{4}$ [6]. Although most of studies are reporting that higher solubilization of sludge leads to the higher $\mathrm{CH}_{4}$ yield. Kim et al [1] observed that under severed pretreatment conditions methane yield decreased. He suspects that after sever sludge treatment soluble sludge fraction that is converted to methane is changing to the fraction that is not convertible to $\mathrm{CH}_{4}$. The whole process can be observed on the Figure 1.

The purpose of the present study was to describe the use of hybrid disintegration (alkaline sludge conditioning [10] in front of partial hydrodynamic disintegration [7, 15, 16], as the pre-treatment procedure) and two stage mesophilic-thermophilic digestion to improve biogas production and sludge hygienization. Anaerobic digester systems are more traditionally designed to operate at mesophilic temperatures between 30 and $38^{\circ} \mathrm{C}$, whereas others operate at thermophilic temperatures, between 50 to $57^{\circ} \mathrm{C}$, and some newly developed systems use a combination in separate stages.

Mesophilic anaerobic sewage sludge digestion has been an established, most often applied in medium and large municipal sewage treatment plants. Single-stage mesophilic anaerobic digestion is one of the most commonly used methods for stabilization and reduction in volume of organic sludge from wastewater treatment processes as well as for the production and recovery of methane gas and has shown good operational performance for a long time. Degradation of volatile suspended solids in the conventional mesophilic anaerobic process is about $40 \%$ at retention times between 30 and 40 days [17]. In the thermophilic range sludge degrades at a higher degradation rate. The mesophilic process of sludge anaerobic digestion has a limited capacity of pathogenic organisms deactivation. The significant disadvantage of this system is that it combines all of the steps of anaerobic digestion into one process, which causes its stability to be controlled by the slowest growing microbes in the process. Because all members of the microbial community are wasted from the system according to the overall solids retention time (SRT), it is typically set at 15 to 20 days, in part, to concentrate methanogens on the system. To overcome these limitations, interest in thermophilic digestion has increased.

In order to minimize costs for solids processing and create an improved quality of biosolids, some wastewater treatment facilities have moved to using advanced anaerobic digestion processes, including thermophilic digestion, acid-gas phased digestion, and temperature-phased anaerobic digestion (TPAD) [18]. Operating one or more stages at thermophilic temperatures has shown several potential advantages, such as higher reduction of volatile solids, higher biogas production and improved solids-liquid separation as well as the increased deactivation of pathogenic organisms [19-21]. However the thermophilic process is much more sensitive to temperature changes and variation of organic loading rates, as well as to the quality of the influent sludge. Also according to Kim et al [22] the thermophilic digested sludge has poor quality in respect to dewatering and has an unpleasant odor.

The negative technological aspects of thermophilic process can be overcome in a two stage, mesophilic - thermophilic, or in a reverse order, process. According to Song et al [20] and Roberts et al [23] two stage processes showed good performance in the effluent quality, methane yield, volatile solid reduction and process stability. Introducing a new process, the combination of mesophilic and thermophilic digestion, a co-phase system - temperature 
phased anaerobic digestion (TPAD) [20, 24], demonstrated better digested sludge quality than that of a single-stage mesophilic or thermophilic anaerobic digestion.

\section{Materials and methods}

Waste activated sludge (WAS) samples, from the secondary settling tanks concentration of suspended solids (SS) in average $9.5 \mathrm{~g} / \mathrm{dm}^{3}$, was taken from a municipal wastewater treatment plant in the south of Poland, working according to the Enhanced Biological Nutrient Removal (EBNR) processes. The plant was designed for a flow of $120000 \mathrm{~m}^{3} / \mathrm{d}$. At present the amount of treated wastewater is about $90000 \mathrm{~m}^{3} / \mathrm{d}$. Solid retention time (SRT) is about 14 days and concentration of mixed liquid suspended solids (MLSS) $4.3-4.7 \mathrm{~g} / \mathrm{dm}^{3}$.

\section{Alkalization}

For chemical WAS disintegration (lysis of microorganisms cells) sodium hydroxide $(\mathrm{NaOH}) 2 \mathrm{M}$ was used. $\mathrm{NaOH}$ was added to samples of activated sludge in amounts sufficient to maintain a given $\mathrm{pH}$ value $(8,9,10$ and 11) for 30 minutes. Approximately from 0.8 to $6 \mathrm{~cm}^{3} \mathrm{NaOH}(2 \mathrm{M})$ per $\mathrm{dm}^{3}$ of WAS.

\section{Hydrodynamic disintegration}

Mechanical disintegration of a $25 \mathrm{dm}^{3}$ of samples of activated sludge was executed in the process of hydrodynamic cavitations. The experimental set up consisted of a 12 bar pressure pump, rating $0.54 \mathrm{kWh}$, output $500 \mathrm{dm}^{3} / \mathrm{h}$, which recirculated sludge from a container, through a $1.2 \mathrm{~mm}$ nozzle. Disintegration was carried out in the periods of 10 , $20,30,40$, and $50 \mathrm{~min}$.

\section{Hybrid disintegration}

The hybrid disintegration process of waste activated sludge (WASD) means, a combination of chemical - alkalization of WAS to $\mathrm{pH}=9$, and then hydrodynamic disintegration for 30 minutes.

\section{Analytical methods}

All chemical analyses were performed for samples before and after each phase of disintegration and during anaerobic digestion. Soluble Chemical Oxygen Demand (SCOD) value was determined according to the procedures given in the Standard Methods for Examination of Water and Wastewater [25]. In the taken samples of the activated sludge content of suspended solids (SS) and volatile suspended solids (VSS) were determined according to the Wastewater Engineering Treatment and Reuse [26].

For colorimetric determinations, a spectrophotometer HACH DR5000 was applied. Chemical analyses were measured for samples before and after each time of disintegration. Centrifugation has been done in all cases for 10 min with $30,000 \mathrm{~g}$.

$\mathrm{pH}$ and conductivity measurements were carried out with a WTW inoLab Level2 meter, equipped with a SenTix K1 electrode for $\mathrm{pH}$. 


\section{The fermentation experiments}

The anaerobic digestion experiments were performed in glass fermenters $\left(3.0 \mathrm{dm}^{3}\right.$ volume). The reactors have been located in thermostatic conditions, with constant temperatures $35 \pm 1^{\circ} \mathrm{C}$ and $55 \pm 1^{\circ} \mathrm{C}$ under mesophilic and thermophilic conditions, respectively. Holding time of 12 days for mesophilic conditions and 13 days for thermophilic conditions were used. The volume of producing biogas was determined by the liquid displacement method ever each day.

Different rates of raw and disintegrated activated sludge have been applied:

- Fermenter 1 - was fed with waste activated sludge (WAS) and inoculum (DS) $(70 \% \mathrm{WAS}+30 \% \mathrm{DS})$, (as a control; average volatile suspended solids removed $4.27 \mathrm{mg} / \mathrm{dm}^{3}$ )

- Fermenter 2 - was fed with WAS (60\% volume of fermenter) and DS (30\% volume of fermenter) and waste activated sludge after the hybrid disintegration (WASD - alkaline $\mathrm{pH} \approx 9$ and 30 minutes of hydrodynamic disintegration), (10\% volume of fermenter; average volatile suspended solids removed $4.28 \mathrm{mg} / \mathrm{dm}^{3}$ )

- Fermenter 3 - was fed with WAS (50\% volume of fermenter) and DS (30\% volume of fermenter) and WASD (20\% volume of fermenter; average volatile suspended solids removed $4.55 \mathrm{mg} / \mathrm{dm}^{3}$ )

- Fermenter 4 - was fed with WAS (40\% volume of fermenter) and DS (30\% volume of fermenter) and WASD (30\% volume of fermenter; average volatile suspended solids removed $4.83 \mathrm{mg} / \mathrm{dm}^{3}$ )

- Fermenter 5 - was fed with WAS (30\% volume of fermenter) and DS (30\% volume of fermenter) and WASD (40\% volume of fermenter; average volatile suspended solids removed $5.44 \mathrm{mg} / \mathrm{dm}^{3}$ )

- Fermenter 6 - was fed with WAS (20\% volume of fermenter) and DS (30\% volume of fermenter) and WASD (50\% volume of fermenter; average volatile suspended solids removed $5.52 \mathrm{mg} / \mathrm{dm}^{3}$ )

The aim of carrying out the experiment of sludge digestion was to show the possibilities to improve and accelerate the anaerobic process. The investigations presented here were performed in 4 stages.

\section{Microbiological analysis}

The samples of WAS for microbiological analysis were collected into glass, hermetically sealed containers with a volume of $0.25 \mathrm{dm}^{3}$. Prior to sampling, the containers were subject to a 30-minute sterilization in autoclave at a temperature of $121{ }^{\circ} \mathrm{C}$ and a pressure of $0.1 \mathrm{MPa}$.

The analyses in WAS were performed before and after the digestion process in terms of Salmonella (most probable number - MPN/g dry weight) and somatic coliphages (SOMPCH, pfu/g dry weight) presence. The determinations of microorganisms were made in accordance with Project Routes (2011-2014), Novel processing routes for effective sewage sludge management procedure. Innovative system solutions for municipal sludge treatment and management. Grant agreement $n^{\circ} 265156$ [27].

As the culture media, the following were used: SMS Agar, Hektoen Enteric Agar, Nutrient Agar and SPS Agar. In order to verify the taxonomic classification of Salmonella $s p$. the API 20E biochemical test and the MUCAP test were used. 
Detection and enumeration of bacteriophages was investigated according to ISO 10705-2:2000 and proposed European standard (http://www.ecn.nl/docs/ society/horizontal/D2_4.5_HOR-HYG_Bact.pdf).

\section{Results and discussion}

Disintegration of activated sludge flocs means partial or complete bacteria cells destruction. As a result, release of intracellular organic matter and enzymes present in cells cytosol results in increase of dissolved organic matter concentration in the liquid it can be measured as SCOD increase (Fig. 2).

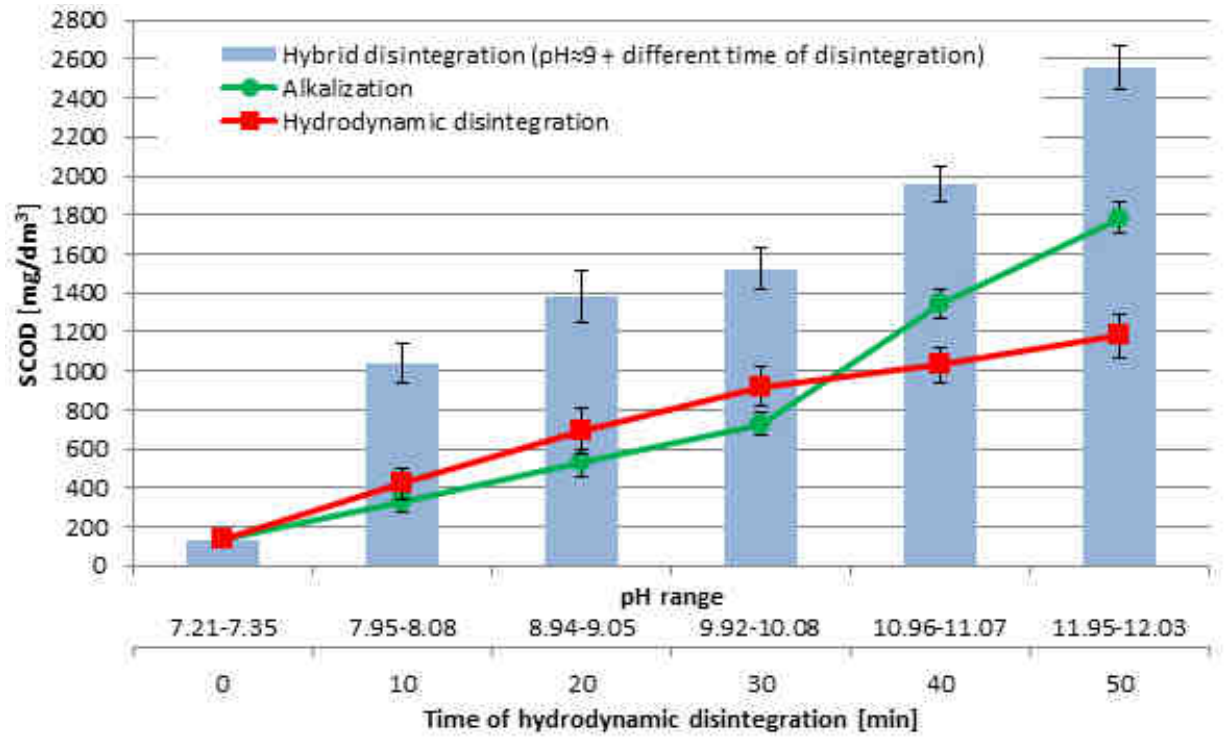

Fig. 2. Changes of SCOD value in liquid phase of activated sludge after alkalization, hydrodynamic and hybrid disintegration

According to the methodology applied during the experiments, the amount of alkaline $(\mathrm{NaOH})$ added was such to achieve the desired $\mathrm{pH}$ measured after 30 minutes. This initial period was set to allow chemical reactions and the penetration of activated sludge flocs by the liquid with the higher $\mathrm{pH}$.

Alkaline sludge treatment leads to the partial dissolution or destruction of flocs structure, and the swelling, and subsequent solubilisation, of cell walls. Alkalization is probably the simplest process for particulate organic matter hydrolysis. The effects of $\mathrm{pH}$ increase have been studied by many authors [28, 29].

Separate processes of alkalization and hydrodynamic disintegration has a pronounced impact on the organic matter dissolution, as shown in Figure 2. The changes of $\mathrm{pH}$ value (ie $\mathrm{pH}$ in the range 11.95-12.03) caused increased of SCOD about $1552 \mathrm{mg} / \mathrm{dm}^{3}$ and 50 minutes of hydrodynamic disintegration resulted insoluble organic matter release about $1048 \mathrm{mg} / \mathrm{dm}^{3}$ (Fig. 2). Recently Lee and Hen [7] conducted similar to our studies tests where they ie were comparing hydrodynamic cavitation with ultrasonification and although 
both these methods are based on the same principle of cavitation, hydrodynamic pretreatment was more effective. Moreover hydrodynamic pretreatment consumed three times less energy than the ultrasonic counterpart [7]. Chen et al [30] investigated the effect of $\mathrm{pH}$ from 4.0 to 11.0 on the WAS hydrolysis. They concluded that under alkaline conditions the VFA's production was significantly higher than under other conditions.

The effects obtained by separate alkaline hydrolysis of activated sludge may be significantly increased by using additional hydrodynamic disintegration. $\mathrm{NaOH}$ molecule has a weak ionic bond and after cavitation hydroxyl radicals are readily formed, they have a high oxidation potential $(\mathrm{E}=2.80)$ and ability to destroy microorganism cells [7]. Subsequent determinations showed an impact of both processes (hybrid disintegration) on the increase of SCOD (Fig. 1). The rise of SCOD value about $2424 \mathrm{mg} / \mathrm{dm}^{3}$ was observed in combination of preliminary alkalization (ie $\mathrm{pH}$ in the range 11.95-12.03) before 50 minutes of hydrodynamic destruction of activated sludge flocs.

To the research on the biogas production chemical (range of $\mathrm{pH}$ 8.94-9.05) and 30 minutes of hydrodynamic disintegration of activated sludge process were used. It was expected that the combination of alkaline pre-treatment and hydrodynamic cavitation will upgrade the effectiveness of anaerobic sludge digestion in terms of biogas production (Table 1) and sludge quantity minimization. Chen et al [30] concluded that under keeping $\mathrm{pH}$ on the level of 10.0 and 11.0, there was no methane generation.

In order to assess the impact of the chosen method of disintegration of the two-stage fermentation process it was decided to replace the 10,20,30, 40 and $50 \%$ by volume of the rector of separate processes and hybrid sludge disintegration. The effect changes in the production of biogas are shown in Table 1.

Table 1

Cumulative biogas production after mesophilic/thermophilic fermentation

\begin{tabular}{|c|c|c|c|}
\hline \multirow{3}{*}{$\begin{array}{c}\text { Volume of disintegrated } \\
\text { sludge }\end{array}$} & \multicolumn{3}{|c|}{ Method of disintegration } \\
\hline & Alkalization (pH $\approx 9$ ) & $\begin{array}{c}\text { Hydrodynamic } \\
\text { disintegration }(30 \text { min) }\end{array}$ & $\begin{array}{c}\text { Hybrid disintegration } \\
\text { (alkalization } \mathrm{pH} \approx 9 \\
+30 \text { min of } \\
\text { hydrodynamic } \\
\text { disintegration) }\end{array}$ \\
\hline & \multicolumn{3}{|c|}{$\begin{array}{l}\text { Cumulative biogas production after mesophilic/thermophilic fermentation } \\
{\left[\mathrm{cm}^{3}\right]}\end{array}$} \\
\hline $70 \%$ WAS + 30\% DS & $2450 \pm 85$ & $2450 \pm 85$ & $2450 \pm 85$ \\
\hline $\begin{array}{l}60 \% \text { WAS }+30 \% \text { DS + } \\
10 \% \text { WASD }\end{array}$ & $2500 \pm 80$ & $2657 \pm 90$ & $3093 \pm 95$ \\
\hline $\begin{array}{l}50 \% \text { WAS }+30 \% \text { DS + } \\
20 \% \text { WASD }\end{array}$ & $2816 \pm 90$ & $2980 \pm 95$ & $3458 \pm 108$ \\
\hline $\begin{array}{l}40 \% \text { WAS }+30 \% \mathrm{DS}+ \\
30 \% \text { WASD }\end{array}$ & $3133 \pm 105$ & $3302 \pm 80$ & $3819 \pm 118$ \\
\hline $\begin{array}{c}30 \% \text { WAS }+30 \% \mathrm{DS}+ \\
40 \% \text { WASD }\end{array}$ & $3327 \pm 115$ & $3502 \pm 103$ & $4056 \pm 125$ \\
\hline $\begin{array}{l}20 \% \text { WAS + 30\% DS + } \\
50 \% \text { WASD }\end{array}$ & $3331 \pm 110$ & $3573 \pm 107$ & $4196 \pm 122$ \\
\hline
\end{tabular}

WAS - waste activated sludge, DS - digested sludge, WASD - waste activated sludge after disintegration

Carried out experiments have confirmed the aforementioned observation, that the disintegration of only a part of WAS is substantiated. The portion of WASD investigated 
was $10,20,30,40$ and $50 \%$ in the mixture of inoculums and not treated WAS. The obtained effects, measured as biogas production for a part of activated sludge hydrodynamically disintegrated after chemical disintegration is presented in Table 1.

In addition to the production of biogas another important factor is the reduction of organic matter. The hybrid disintegration process released organic matter to the liquid phase, and has been observed it is the most suitable material for increase yield of biogas (Fig. 3).

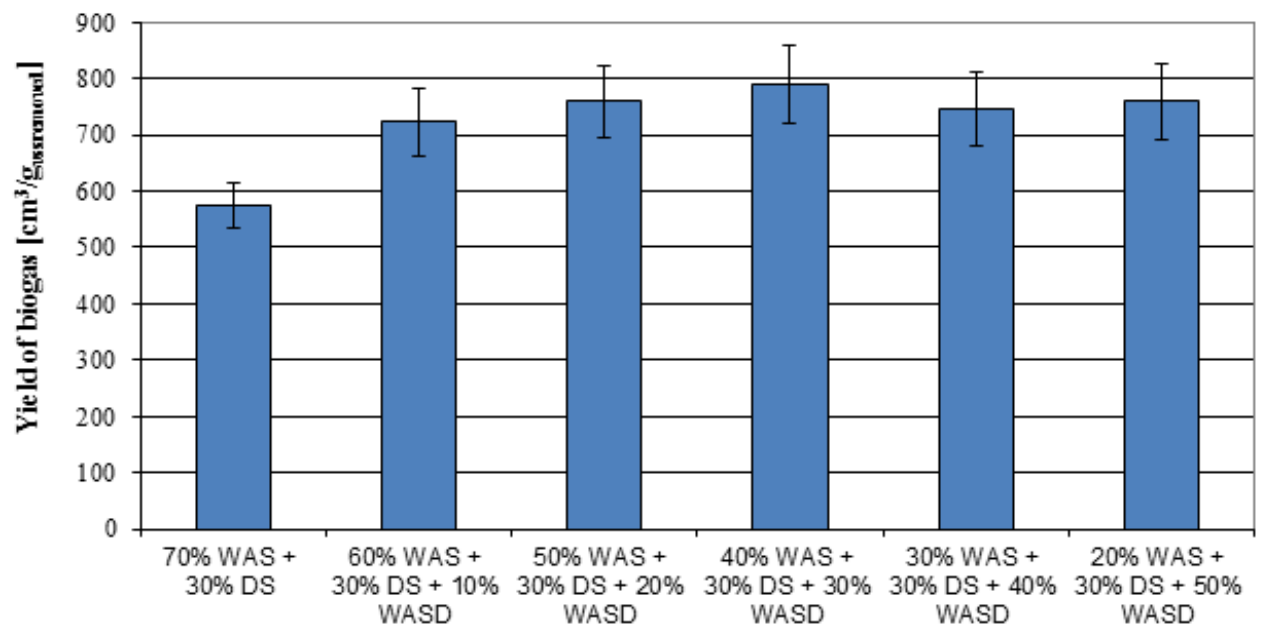

Fig. 3. Changes of yield of biogas with increased volume of WASD

The yield of biogas in the case of additive of WASD was always higher compared to the sample without addition WASD (Fig. 3). The addition 10, 20, 30, 40 and 50\% of volume of WASD caused the increase yield of biogas about 26, 32, 38, 30 and 33\%, respectively. The optimal yield of biogas has been observed in the sample with $30 \%$ of the volume of WASD addition.

National and international regulations [31-33] require that sludge shall be stabilized and hygienized before land application. Hygienization is a process intended to reduce the content of pathogenic microorganisms to a safe level. In contrast to bacteria, virus in general, are sensitive to heat and are inactivated by increased temperature. As previously mentioned the aim of study was determined the effect of two-stage anaerobic fermentation on the effective reduction of microorganisms in the remaining sludge to utilization in agricultural. Sludge produced by wastewater treatment plants treat fecal material contains pathogenic microorganisms. The most important pathogenic microorganisms are those transmitted by the fecal-oral route and include bacteria, viruses, and parasites. Fecal microorganisms that are pathogenic or non-pathogenic and are present in sewage are transferred to sludge, where their concentration is higher than it is in wastewater [34-36]. Moreover, many microorganisms survive better when they are associated with solids than when they are suspended in water [37-39], and at some stage of treatment of sludge, the 
growth of some pathogenic bacteria (for example, Salmonella) may be supported [36]. Therefore, both treated sludge and raw sludge are sources of pathogenic microorganisms.

The average numbers of microorganisms indicators are shown in Table 2.

Table 2

The average numbers of microorganisms indicators before and after mesophilic/thermophilic fermentation process

\begin{tabular}{|c|c|c|c|c|c|c|c|}
\hline \multirow[b]{3}{*}{ Sample } & SOM & IPCH & \multirow{3}{*}{$\begin{array}{c}\text { Percent of } \\
\text { elimination } \\
{[\%]}\end{array}$} & \multirow{3}{*}{$\begin{array}{c}\text { SOMPCH } \\
\text { [pfu/g dry } \\
\text { weight] } \\
\text { End of } \\
\text { thermo- } \\
\text { philic } \\
\text { process }\end{array}$} & \multirow{2}{*}{\multicolumn{3}{|c|}{$\begin{array}{c}\text { Salmonella MPN } \\
\text { [MPN/g dry weight] }\end{array}$}} \\
\hline & \multicolumn{2}{|c|}{ [pfu/g dry weight] } & & & & & \\
\hline & $\begin{array}{c}\text { Start } \\
\text { of the } \\
\text { process }\end{array}$ & $\begin{array}{c}\text { End of } \\
\text { meso- } \\
\text { philic } \\
\text { process }\end{array}$ & & & $\begin{array}{c}\text { Start of the } \\
\text { process }\end{array}$ & $\begin{array}{c}\text { End of } \\
\text { mesophilic } \\
\text { process }\end{array}$ & $\begin{array}{c}\text { End of } \\
\text { thermophilic } \\
\text { process }\end{array}$ \\
\hline $70 \%$ WAS + 30\% DS & $4.16 \cdot 10^{5}$ & $3.63 \cdot 10^{5}$ & 12.7 & 0 & $>11$ & 11 & 0 \\
\hline $\begin{array}{c}60 \% \text { WAS + 30\% DS } \\
+10 \% \text { WASD }\end{array}$ & $3.83 \cdot 10^{5}$ & $3.43 \cdot 10^{5}$ & 10.4 & 0 & $>11$ & 11 & 0 \\
\hline $\begin{array}{c}50 \% \text { WAS }+30 \% \text { DS } \\
+20 \% \text { WASD }\end{array}$ & $2.16 \cdot 10^{5}$ & $1.87 \cdot 10^{5}$ & 13.4 & 0 & 11 & 2,4 & 0 \\
\hline $\begin{array}{c}40 \% \text { WAS }+30 \% \text { DS } \\
+30 \% \text { WASD }\end{array}$ & $9.16 \cdot 10^{4}$ & $7.76 \cdot 10^{4}$ & 15.3 & 0 & 11 & 2,1 & 0 \\
\hline $\begin{array}{c}30 \% \text { WAS }+30 \% \text { DS } \\
+40 \% \text { WASD }\end{array}$ & $8.80 \cdot 10^{4}$ & $7.49 \cdot 10^{4}$ & 14.8 & 0 & 4,6 & 2,1 & 0 \\
\hline $\begin{array}{c}20 \% \text { WAS }+30 \% \text { DS } \\
+50 \% \text { WASD }\end{array}$ & $6.05 \mathrm{E}+04$ & $5.11 \mathrm{E}+04$ & 15.5 & 0 & 2,1 & 1,5 & 0 \\
\hline
\end{tabular}

Bacteriophages included SOMPCH are potential model organisms for determining the influence of sludge treatment on the enteric virus load [34]. Some bacteriophages are structurally similar to human enteroviruses and may be vulnerable to the same inactivating mechanisms. Furthermore, phages are much more easily and inexpensively assayed than enteroviruses. These considerations make bacteriophages an attractive possibility as indicators system for enteroviruses inactivation, In fact, phages have been proposed as indicators of viral pollution.

Depending on the dose of WASD after mesophilic fermentation was observed a slight reduction SOMPCH (from 10.4 to $15.5 \%$ ) (Table 1). Similar results of SOMPCH reduction (8.5\%) after mesophilic fermentation obtained by Mandilara et al [40].

The genus Salmonella are the ethiological factor of from 300 thousand to even 4 million food poisonings annually [41], whereas the mortality can reach up to $30.6 \%$ [42]. Salmonellosis constitutes a major health problem (Salmonella sp. usually causes an intestinal infection characterized by diarrhea, fever, and abdominal cramps that often lasts one week or longer); it is therefore necessary to properly handle natural fertilizers (including sewage sludge) which can lead to the contamination of the natural environment. After mesophilic anaerobic digestion, a gradual decrease in the population count of Salmonella sp. was observed. Similar results after mesophilic fermentation was observed by [43]. Kumar et al [44] investigated the survival of some pathogens in anaerobic batch reactors. Salmonella sp. survived up to 10 days at temperatures of $35^{\circ} \mathrm{C}$. The survival of Salmonella typhi increased from 20 to 35 days when the solid contents were increased from $9 \%$ to $15 \%$.

Kearny et al [45] investigated the efficiency of full scale anaerobic digestion reactor operated at the $28^{\circ} \mathrm{C}$ to remove pathogenic bacteria. Escherichia coli, Salmonella 
typhimurium, Yersinia enterocolitica, Listeria monocytogenes and Campylobacter jejuni were only partially removed during the treatment period.

The total elimination of analyzing microorganisms indicators was after two stage anaerobic digestion.

\section{Conclusions}

Chemical alkalization, hydrodynamic cavitation and both of them (hybrid method) are a suitable method to destroy of activated sludge structure. In this study, these methods were examined, with the aim of releasing organic matter. The most important conclusions of this study are:

- Separate processes of alkalization and hydrodynamic disintegration has a pronounced impact on the organic matter dissolution. The changes of $\mathrm{pH}$ value (ie $\mathrm{pH}$ in the range 11.95-12.03) caused increased of SCOD about $1552 \mathrm{mg} / \mathrm{dm}^{3}$ and 50 minutes of hydrodynamic disintegration resulted insoluble organic matter release about $1048 \mathrm{mg} / \mathrm{dm}^{3}$.

- Hybrid disintegration significantly increase of SCOD. The rise of SCOD value about $2424 \mathrm{mg} / \mathrm{dm}^{3}$ was observed in combination of preliminary alkalization (ie $\mathrm{pH}$ in the range 11.95-12.03) before 50 minutes of hydrodynamic destruction of activated sludge flocs.

- The portion of WASD $(10,20,30,40$ and $50 \%$ of volume) in anaerobic reactors improves the biogas production. The sample with 50\% WASD of volume caused an increase of biogas production about $1746 \mathrm{~cm}^{3}$ (71\% higher production).

- The yield of biogas in the case of additive of WASD was always higher compared to the sample without addition WASD. The addition 10, 20, 30, 40 and $50 \%$ of volume of WASD caused the increase yield of biogas about 26, 32, 38, 30 and 33\%, respectively. The optimal yield of biogas has been observed in the sample with $30 \%$ of the volume of WASD addition.

- Depending on the dose of WASD after mesophilic fermentation was observed a slight reduction SOMPCH (from 10.4 to 15.5\%) and Salmonella sp. whereas total elimination of analyzing microorganisms indicators was observed after two stage anaerobic digestion.

\section{Acknowledgements}

This work was supported by the EU ROUTES project (Contract No 265156, FP7 2007-2013, THEME [ENV.2010.3.1.1-2] Innovative system solutions for municipal sludge treatment and management).

\section{References}

[1] Kim D-H, Cho S-K, Lee M-K, Kim M-S. Bioresource Technol. 2013;143:660-664. DOI: 10.1016/j.biortech.2013.06.058.

[2] Kuglarz M, Karakashev D, Angelidaki I. Bioresource Technol. 2013;134:290-297. DOI: 10.1016/j.biortech.2013.02.001.

[3] Müller J. Desintegration as a key-step in sewage treatment. Water Sci Technol. 2000;41:123-130. 
[4] Neyens E, Baeyens J, Dwil R, de Heyder B. Advanced sludge treatment affects extracellular polymeric substances to improve activated sludge dewatering. J Hazard Mater. 2004;106B:83-92. doi.org/10.1016/j.jhazmat.2003.11.014

[5] Dohanyos M, Zabranska J, Jenicek P, Fialka P, Kajan M. Anaerobni cistirenske technologie (Technologies of anaerobic treatment). Brno; NOEL: 2000; 344.

[6] Dohanyos M, Zabranska J, Kutil J, Jenicek P. Improvement of anaerobic digestion of sludge. Water Sci Technol. 2004;49:89-96.

[7] Lee I, Han J-I. Ultrasonics Sonochem. 2013;20(6):1450-1455. DOI: 10.1016/j.ultsonch.2013.03.006.

[8] Li YY, Noike T. Upgrading of anaerobic digestion of waste activated sludge by thermal pretreatment. Water Sci Technol. 1992;26:857-866.

[9] Kepp U, Machenbach I, Weisz N, Solheim OE. Enhanced stabilisation of sewage sludge through thermal hydrolysis. Water Sci Technol. 2000;42:89-96.

[10] Lin JG, Chang CN, Chang SC. Bioresource Technol. 1997;62:85-90. DOI: 10.1016/S09608524(97)00121-1.

[11] Rooksby F, Amato A, Mormede S, Purcell N. Sonix treatment for biosolids-making the most out of renewable energy. In: 7th European Biosolids and Organic Residual Conf. AquaEnviro. Wakefield: 2002.

[12] Kim T-Hun, Kim T-Hyun, Yu S, Nam Yk, Choi D-K, Lee SR, Lee M-J. Solubilization of waste activated sludge with alkaline treatment and gamma ray irradiation. J Ind Eng Chem. 2007;13:1149-1153.

[13] Grübel K, Machnicka A, Wacławek S. Ecol Chem Eng S. 2013;20(2):343-351. DOI: 10.2478/eces-2013-0025.

[14] Li H, Zou S, Li Ch, Jin Y. Bioresource Technol., 2013;140:187-191. DOI: 10.1016/j.biortech.2013.04.093.

[15] Grübel K, Machnicka A. Water Environ Res. 2009;81:2420-2426. DOI: 10.2175/106143009X425915.

[16] Grübel K, Machnicka A, Suschka J. Environmental Eng III. 2010;40:279-284. DOI: 10.1201/b10566-46.

[17] Roš M, Zupančič GD. Theromophilic anaerobic digestion of waste activated sludge. Acta Chimica Slovenica. 2003;50:359-374.

[18] Schafer PL, Farrell JB, Newman G, Vandenburgh S. Advanced anaerobic digestion processes. Water Environ Technol. 2003;15:38-44.

[19] Zitomer DH, Bachman, TC, Vogel DS. Thermophilic anaerobic digester with ultrafilter for solids stabilization. Water Sci Technol. 2005;52:525-530.

[20] Song Chy Y, Kwon JS, Woo HJ. Wat Res. 2004;38:1653-1662. DOI: 10.1016/j.watres.2003.12.019.

[21] Cheunbarn T, Pagilla K. J Environ Eng. 2000;126:796-801. DOI: 10.1061/(ASCE)07339372(2000)126:9(796).

[22] Kim YK, Bae JH, Oh BK, Lee WH, Choi JW. Bioresource Technol. 2002;82:157-164. DOI: 10.1016/S0960-8524(01)00177-8.

[23] Roberts R, Son L, Foster CF. J Chem Technol Biotechnol. 1999;74:445-450. DOI: 10.1002/(SICI)10974660(199905)74:5<445::AID-JCTB65>3.0.CO;2-0.

[24] Ge H, Jensen PD, Batstone DJ. Water Res. 2011;45:1597-606. DOI: 10.1016/j.watres.2010.11.042.

[25] Rice EW, Baird RB, Eaton AD, Clesceri LS. Standard Methods for the Examination of Water and Wastewater (22nd edition). Washington: American Public Health Association; 2012.

[26] Tchobanoglous G, Burton FL, Stensel HD. Wastewater Engineering: Treatment and Reuse (4th edition). Metcalf \& Eddy, Inc.; 2002.

[27] Project Routes (2011-2014), Novel processing routes for effective sewage sludge management procedure. Innovative system solutions for municipal sludge treatment and management. Grant agreement $\mathrm{n}^{\circ} 265156$. ISO 10705-2:2000.

[28] Kim J, Park C, Kim T-H, Lee M, Kim S, Kim SW, Lee J. Effects of various pretreatments for enhanced anaerobic digestion with waste activated sludge. J Biosci Bioeng. 2003;95:271-275.

[29] Li H, Jin Y, Mahar RB, Wang Z, Nie Y. Bioresources Technol. 2008;99:5140-5144. DOI: 10.1016/j.biortech.2007.09.019.

[30] Chen Y, Jiang S, Hongying Y, Zhou Q, Gu G. Water Res. 2007;41:683-689. DOI: 10.1016/j.watres.2006.07.030.

[31] European Directive 86/278 (European Union, 1986).

[32] European Working Document on Sludge (European Union, 2000).

[33] 40 CFR Part 503' (U.S. EPA, 1995).

[34] Lasobras J, Dellunde J, Jofre J, Lucena F. J App Microbiol. 1999;86:723-729. DOI: 6924/10/98.

[35] Strauch D. Pathogenic micro-organisms in sludge. Anaerobic digestion and disinfection methods to make sludge usable as fertiliser. Eur Water Manag. 1998;1:12-26.

[36] Williams FP, Hurst CJ. Water Res. 1988;22:847-851. DOI: 10.1016/0043-1354(88)90022-X. 
[37] Gibbs RA, Hu CJ, Ho GE, Unkovich I. Regrowth of faecal coliforms and Salmonella in stored biosolids and soil amended with biosolids. Water Sci Technol. 1997;35:269-275.

[38] Scheuerman PR, Farrah SR, Bitton G. Water Res. 1991;3:241-245. DOI: 10.1016/0043-1354(91)90002-8.

[39] Straub TM, Pepper IL, Gerba CP. App Environ Microbiol. 1992;58:636-645. DOI: 0099-2240/92/020636$06 \$ 02.00 / 0$.

[40] Mandilara GD, Smeti EM, Mavridou AT, Lambiri MP, Vatopoulos AC, Rigas FP. FEMS Microbiol Lett. 2006;263:119-126. DOI: 10.1111/j.1574-6968.2006.00414.x.

[41] U.S. Department of Agriculture, Food Safety and Inspection Service. Farm-to-table safety system; Salmonella enteritidis contamination, control and reduction. Fed Regist. 1998;63:27502-27511.

[42] Kiessling CR, Cutting JH, Loftis M, Kiessling WM, Datta AR, Sofos JN. Antimicrobial resistance of food-related Salmonella isolates. J Food Prot. 2002;65:603-608.

[43] Paluszak Z, Skowron K, Olszewska H, Skowron KJ, Bauza-Kaszewska J, Gryń G. Sanitization efficacy of anaerobic digestion and aeration of slurry from the aspect of limiting emission of Salmonella into the environment. Ann Agric Environ Med. 2012;19(3):427-430.

[44] Kumar R, Gupta MK, Kanwar SS. Fate of bacterial pathogens in cattle dung slurry subjected to anaerobic digestion. World J Microbiol Biotechnol. 1999;15:335-338.

[45] Kearney TE, Larkin MJ, Levett PN. J App Bacteriol. 1993;74:86-93. DOI: 10.1111/j.13652672.1993.tb03000.x

\title{
FERMENTACJA MEZOFILOWO-TERMOFILOWA OSADU DEZINTEGROWANEGO W PROCESIE HYBRYDOWYM
}

\footnotetext{
${ }^{1}$ Zakład Mikrobiologii i Biotechnologii Środowiskowej, Instytut Ochrony i Inżynierii Środowiska Wydział Nauk o Materiałach i Środowisku, Akademia Techniczno-Humanistyczna, Bielsko-Biała

${ }^{2}$ Instytut Nanomateriałów, Zaawansowanych Technologii i Innowacji, Politechnika w Libercu
}

\begin{abstract}
Abstrakt: Decydujące znaczenie dla przeprowadzonego zadania badawczego miały wyniki badań dotyczące jednostkowych procesów dezintegracji hydrodynamicznej i alkalizacji. Połączenie kawitacji hydrodynamicznej (30 minut trwania procesu) i alkalizacji (przy $\mathrm{pH} \approx 9$ ) w celu destrukcji osadu czynnego powodowało znaczące uwolnienie materii organicznej o $1383 \mathrm{mg} / \mathrm{dm}^{3}$ w porównaniu do jednostkowych procesów. Tak duży wzrost wartości ChZT przełożył się na istotny wzrost wydajności produkcji biogazu w procesie dwustopniowej fermentacji mezofilowo-termofilowej. Wzrost wydatku wyniósł od 26 do 38\% w zależności od udziału osadu dezintegrowanego. Działanie dwustopniowej fermentacji skutkowało higienizacją osadu czynnego. Analiza mikrobiologiczna wpływu procesu fermentacji ze zróżnicowanym udziałem osadu dezintegrowanego hybrydowo została dokonana zgodnie ze wskaźnikami mikrobiologicznymi: Salmonella spp. oraz colifagi. Otrzymane wyniki świadczą o skuteczności prowadzenia procesu dwustopniowego w porównaniu z fermentacją jednostopniową mezofilową, po której nie zawsze następuje całkowita eliminacja ww. wskaźników.
\end{abstract}

Słowa kluczowe: dezintegracja hybrydowa, dwustopniowa fermentacja, biogaz, higienizacja osadów ściekowych 